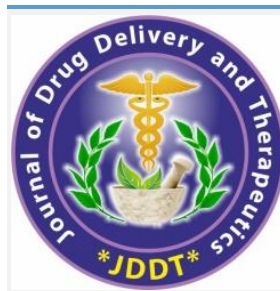

2
Available online on 15.03.2021 at http://jddtonline.info

\section{Journal of Drug Delivery and Therapeutics}

Open Access to Pharmaceutical and Medical Research

(C) 2011-21, publisher and licensee JDDT, This is an Open Access article which permits unrestricted non-commercial use(CC By-NC), provided the original work is properly cited

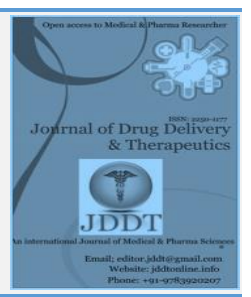

Review Article

\title{
COVID-19 Vaccine Race: An Overview and Update
}

\author{
Md. Rayhan Chowdhury, Shirmin Islam, Mohammad Nurul Matin* \\ Molecular Genetics Laboratory, Department of Genetic Engineering and Biotechnology, University of Rajshahi, Rajshahi-6205, Bangladesh
}

\begin{tabular}{ll}
\hline Article Info: \\
\hline
\end{tabular}

Cite this article as:

Chowdhury MR, Islam S, Matin MN, COVID-19 Vaccine Race: An Overview and Update, Journal of Drug Delivery and Therapeutics. 2021; 11(2):171-177

DOI: http://dx.doi.org/10.22270/jddt.v11i2.4752

\section{*Address for Correspondence:}

Mohammad Nurul Matin, PhD, Professor, Department of Genetic Engineering and Biotechnology, University of Rajshahi, Rajshahi-6205, Bangladesh

\begin{abstract}
A sudden health crisis has shut down the entire world for almost a year due to a new virus called Covid-19 and thus the WHO has declared the COVID-19 as a pandemic disease. As vaccines stimulate the immune system to fight against future infections, thereby conferring immunity, so far, vaccine development in a race throughout the world. Therefore, disseminating the overview of the vaccine development at present with their critical situation for COVID-19 is the aim of this review. The world is looking eagerly for a potential vaccine candidate that can save every life. Here, we reported the overview of the possible types of vaccines against Covid-19 as well as a glimpse of vaccine race with different phases of clinical trial data, comparison of the rate of success of phase-III clinical trials and their safety, and drawbacks with the present status. We have studied literature from clinical trial data of respective vaccine candidates published in the journals and collected data from databases dedicated to corona vaccine and the vaccine company's website to enrich our review and aiming to focus on clinical trial data stages, how consequences it faces, and how to position it belongs towards a successful vaccine candidate.
\end{abstract}

Keywords: COVID-19, SARS-CoV-2, COVID-19 vaccine, Clinical trial.

\section{Introduction}

In late November of 2019, a highly contagious respiratory virus was noticed in Wuhan, China and later, it has spread all over the world ${ }^{1}$. Along with the other zoonotic viruses (SARS and MERS) of the beta corona viridae family, the bat is thought to be the source of SARS-CoV-2. 2,3. Although the mortality rate of Covid-19 (1.4\%) is comparatively low compared with other coronaviruses, the contagion rate of Covid-19 (R0 = 2-3) is higher than that of the Spanish flu (0.9-2.0), which made the virus even more deadly ${ }^{4-6}$. Generally, people of all ages may be attacked by the virus but older, and patients with acute respiratory distress syndrome are more prone to death 7,8 . Current reports indicate that as of January 04, 2021, approximately 85,599,504 Covid-19 positive cases had been identified and 1,853,005 people had lost their lives due to this Covid-19 attack.

\section{(https://www.worldometers.info/coronavirus/?utm_campai} gn=homeAdvegas1?)

Like SARS virus, ACE2 (angiotensin converting enzyme 2) is also the receptor for SARS-CoV-2 through which the virus enter the human body and destroy our immune system, and multiply ${ }^{9}$. The whole genome sequence of covid-19 is available in gene bank since early March (Gene Bank ID: MN908947.3) ${ }^{10}$. With $30 \mathrm{~kb}$ genome, four major structural proteins (spike protein, membrane protein, envelope protein and nucleocapside) and non-structural proteins, SARS-Covid2 is a single stranded RNA virus 11-13. Various sites of Covid19 have been selected as drug and vaccine targets to inactivate the virus, including $\mathrm{S}$ proteins ${ }^{11}, \mathrm{~N}$ protein ${ }^{14}$, mpro
15, RNA dependent RNA polymerase ${ }^{16}$, etc. With the onset of the second wave of Covid-19, infections in the last week of November increased about $2 \%$ over the previous weeks. Scientists are speculating that the second wave may be worse than the first ${ }^{17}$. Several countries are planning to reimpose lockdown to combat the spread of virus ${ }^{18}$. Now nothing but an effective and safe vaccine will allow the world to return to its normal state. Although various researches are underway to identify and control the virus, so far no positive vaccine has been found against it ${ }^{19}$. However, vaccine development is a long term process with several phases, an unpredictable race is in full swing with more than 160 vaccine candidates in several countries. All updated information regarding the COVID-19 vaccine is being published by the WHO and the necessary information regarding the COVID-19 vaccine is regularly published in the scientific literature 20,21 . Although vaccine trials against Covid-19 began in China on February 15, 2020 22, it could not stay forward at the race. So far, BNT162b2 is the most likely by the UK. All eyes are on the race of the Covid-19 vaccine ${ }^{23}$. This review is intended to provide an overview of dedicated efforts to provide effective vaccines against COVID-19 that is crimpling the world.

\section{Why vaccine is important for Covid-19 patients}

According to WHO, vaccination is a safe and effective way to protect people from harmful diseases before they come into contact with them. Protection from viral infections is developed by induction of immune response through virus- 
neutral antibodies against the diseased particle, which is generally achieved through vaccination.

Vaccines have saved millions of people's lives in the past, so for overcoming this pandemic we are eagerly waiting for an effective vaccine. Natural plant compounds are getting priority in this vaccine development. As plants phytochemicals are considered safe for human bodies so from the ancient time plant compounds are being used for this pharmaceutical purpose ${ }^{24}$. Although the development of a vaccine is a long-term process with several steps and issues, scientists around the world are working hard to reduce the time duration to develop an effective vaccine against Covid-19 24. Each potential vaccine candidate need to be evaluated for safety, immunity and protective efficacy in humans before being licensed 25 .

\section{Covid-19 and its vaccine target}

Within short period of outbreak on 10 January'2020 the genome sequence of Covid-19 become available on the web side of the Virology department and later after several sources submitted almost whole genome sequence of Covid19 on GISAID database ${ }^{26}$. Like other known corona virus SARS-CoV-2 uses host's ACE receptor to seize the target cell through its unique N-glycosylated spike proteins (S2 subunit) ${ }^{27}$. As the head of the virus appears to be less shielded, indicating that the protein could be an easier target to defeat the virus ${ }^{28}$. In addition to the $S$ protein, the other proteins such as $\mathrm{N}$ proteins, $\mathrm{M}$ proteins, non-structural proteins (NSPS) and ancillary proteins may have the potentiality to serve as antigens. The viral main proteinase, 3CLpro, is thought to be an effective target for drug development.

In contrast to COVID-19, there are a variety of vaccine candidates, ranging from conventional whole pathogen vaccines (live-attenuated vaccines, inactivated vaccines etc.) to various new generation vaccines (recombinant protein vaccines, viral vector-based vaccines, plasmid DNA vaccine etc. ${ }^{29}$. Currently, the most clinically advanced COVID-19 vaccines are non- replicating viral vector vaccine $(28 \%)^{30}$ or protein sub-unit vaccine $(26.5 \%) 31$, other types of vaccine candidates include inactivated vaccine $(19.5 \%)$, RNA-based vaccine $(13 \%)$, DNA based vaccine $(6 \%)$ and replicating viral vector vaccine $(5 \%)$ etc.

\section{Vaccine strategies and the race of COVID-19 Vaccine}

To develop a successful vaccine candidate is a long term process. In addition, several strategies are followed and different targets are identified to develop different types of vaccines including Live attenuated, Inactivated vaccine, RNA vaccine, DNA vaccine, Replicating Viral Vector, Non replicating viral vector, Protein subunits, Virus Like Particles (VLP), etc. Here, advantages, limitations, and previous success of above-mentioned type of vaccines are outlined, and finally, it has paved the way towards the race of COVID19 vaccine development (Table 1 and Fig. 1).

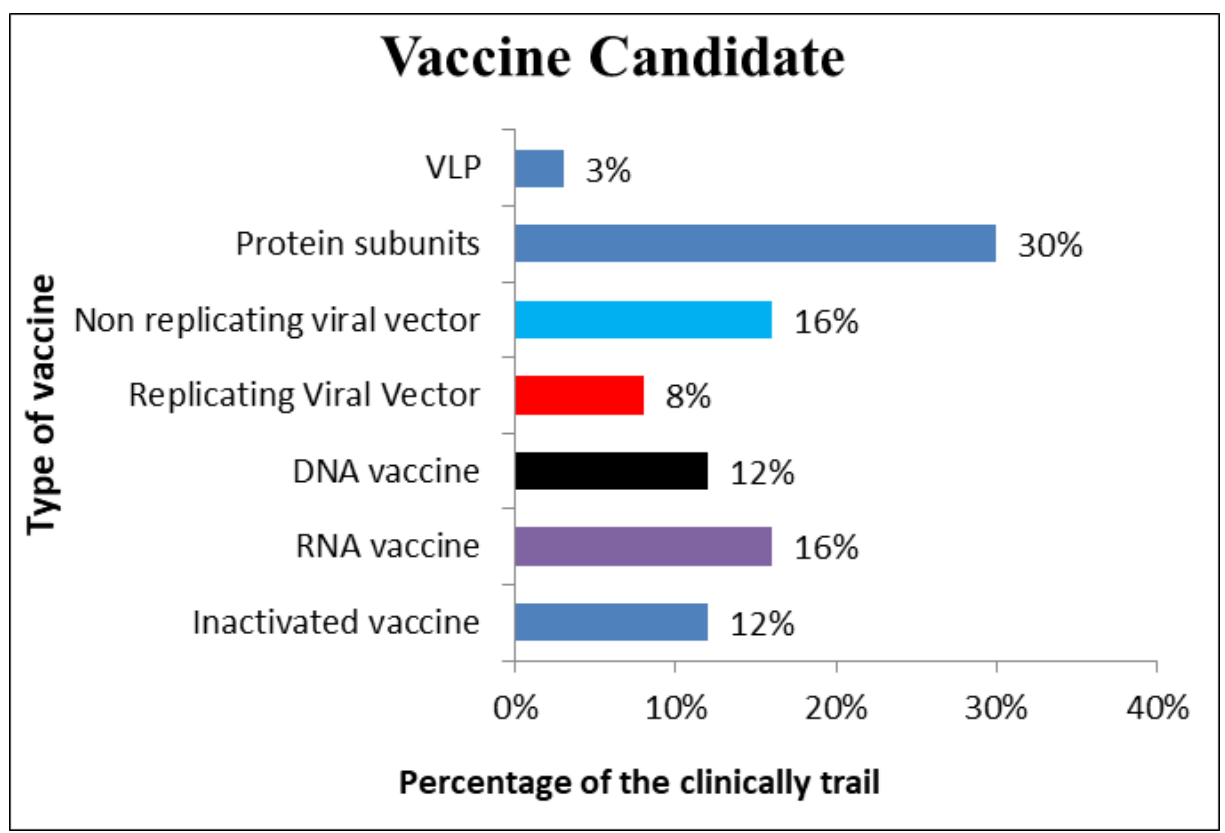

Figure 1: Outline of different vaccine candidates and its position in clinical trial

Source: https://covid-nma.com/vaccines/mapping/\#void 
Table 1: Outline of vaccine strategies and platform for COVID-19 vaccine development

\begin{tabular}{|c|c|c|c|c|c|c|}
\hline Vaccine type & Attenuation & $\begin{array}{l}\text { Advantages on the } \\
\text { field of Covid-19 }\end{array}$ & Limitations & $\begin{array}{l}\text { Previous } \\
\text { success history }\end{array}$ & $\begin{array}{l}\text { On the race } \\
\text { of Covid-19 }\end{array}$ & Ref \\
\hline $\begin{array}{l}\text { a) Live } \\
\text { attenuated }\end{array}$ & $\begin{array}{l}\text { Live attenuated virus } \\
\text { vaccine is produced by } \\
\text { mutating or deleting the } \\
\text { virulence genes of a live } \\
\text { virus. }\end{array}$ & $\begin{array}{l}\text { Deletion of non- } \\
\text { structural genes } \\
\text { and deoptimization } \\
\text { of codon are being } \\
\text { used to develop } \\
\text { vaccine against } \\
\text { Covid-19. Adjuvant } \\
\text { is not necessary. }\end{array}$ & $\begin{array}{l}\text { Genetic } \\
\text { reversion is } \\
\text { the most } \\
\text { prominent } \\
\text { barrier against } \\
\text { the vaccine } \\
\text { development. } \\
\text { Storage issues }\end{array}$ & $\begin{array}{l}\text { BCG vaccine, } \\
\text { MMR vaccine; } \\
\text { Rotavirus } \\
\text { vaccine and } \\
\text { Poliovirus } \\
\text { vaccine. }\end{array}$ & $\begin{array}{l}1 \text { vaccine is } \\
\text { on the race of } \\
\text { clinical trial. }\end{array}$ & 31 \\
\hline $\begin{array}{l}\text { b) Inactivated } \\
\text { vaccine }\end{array}$ & $\begin{array}{l}\text { Through chemical and } \\
\text { physical treatment the } \\
\text { whole virus particle is } \\
\text { inactivated. }\end{array}$ & $\begin{array}{l}\text { Generally, destroy } \\
\text { the viral RNA; } \\
\text { adjuvant is } \\
\text { necessary to boost } \\
\text { up the immunity. }\end{array}$ & $\begin{array}{l}\text { Adjuvants may } \\
\text { show side } \\
\text { effects. }\end{array}$ & $\begin{array}{l}\text { IPV vaccine, } \\
\text { whooping cough } \\
\text { vaccine, rabies } \\
\text { vaccine, } \\
\text { hepatitis A virus } \\
\text { vaccine }\end{array}$ & $\begin{array}{l}7 \text { vaccines } \\
\text { are on the } \\
\text { race of } \\
\text { clinical trial. }\end{array}$ & $\begin{array}{l}32- \\
34\end{array}$ \\
\hline c) RNA vaccine & $\begin{array}{l}\text { RNA vaccines are prepared } \\
\text { using an mRNA sequence } \\
\text { that codifies for a specific } \\
\text { antigen and when induced } \\
\text { in the body, the antigen } \\
\text { could be recognized by the } \\
\text { immune system of the body } \\
\text { to fight. }\end{array}$ & $\begin{array}{l}\text { Lipid nano particles } \\
\text { are being used to } \\
\text { deliver the viral } \\
\text { mRNA sequence. } \\
\text { The RNA could } \\
\text { work as self } \\
\text { adjuvant. }\end{array}$ & $\begin{array}{l}\text { There is a big } \\
\text { storage issue. } \\
\text { In vivo vaccine } \\
\text { delivery and } \\
\text { uptake is a } \\
\text { challenging } \\
\text { task. }\end{array}$ & Cancer therapy & $\begin{array}{l}10 \text { vaccines } \\
\text { are on the } \\
\text { race of } \\
\text { clinical trial }\end{array}$ & $\begin{array}{l}35,3 \\
6\end{array}$ \\
\hline d) DNA vaccine & $\begin{array}{l}\text { Genetically engineered DNA } \\
\text { particle is used to code viral } \\
\text { protein. }\end{array}$ & $\begin{array}{l}\text { Circular DNA } \\
\text { plasmid is used } \\
\text { which later } \\
\text { transcribed into } \\
\text { mRNA. Solely } \\
\text { genetic material is } \\
\text { used. }\end{array}$ & $\begin{array}{l}\text { Weaker } \\
\text { induction of } \\
\text { immunity. } \\
\text { Insertional } \\
\text { mutation may } \\
\text { occur. }\end{array}$ & $\begin{array}{l}\text { Partially } \\
\text { effective against } \\
\text { Swine flue }\end{array}$ & $\begin{array}{l}7 \text { vaccines } \\
\text { are on the } \\
\text { race of } \\
\text { clinical trial }\end{array}$ & $\begin{array}{l}32 \\
37\end{array}$ \\
\hline $\begin{array}{l}\text { e) Replicating } \\
\text { Viral Vector }\end{array}$ & $\begin{array}{l}\text { The vaccine mimics what } \\
\text { happens during natural } \\
\text { infection with certain } \\
\text { pathogens - especially } \\
\text { viruses. }\end{array}$ & $\begin{array}{l}\text { No antigenic } \\
\text { particle is used } \\
\text { instead of the } \\
\text { vaccine influence } \\
\text { the body to produce } \\
\text { antigen. So, strong } \\
\text { immune response is } \\
\text { produced in body. }\end{array}$ & $\begin{array}{l}\text { It may be } \\
\text { harmful for } \\
\text { immune } \\
\text { compromised } \\
\text { patients. }\end{array}$ & Ebola & $\begin{array}{l}5 \text { vaccines } \\
\text { are on the } \\
\text { race of } \\
\text { clinical trial }\end{array}$ & $\begin{array}{l}33 \\
38\end{array}$ \\
\hline $\begin{array}{l}\text { f) Non } \\
\text { replicating } \\
\text { viral vector }\end{array}$ & $\begin{array}{l}\text { Non-replicating vector } \\
\text { vaccines generally enter } \\
\text { cells and produce the } \\
\text { vaccine antigen, but no new } \\
\text { virus particles are formed. }\end{array}$ & $\begin{array}{l}\text { The viral vector } \\
\text { vaccines result in } \\
\text { endogenous antigen } \\
\text { production, both } \\
\text { humoral and } \\
\text { cellular immune } \\
\text { responses are } \\
\text { stimulated. }\end{array}$ & $\begin{array}{l}\text { Booster doses } \\
\text { are needed. }\end{array}$ & No & $\begin{array}{l}10 \text { vaccines } \\
\text { are on the } \\
\text { race of } \\
\text { clinical trial }\end{array}$ & $\begin{array}{l}33 \\
39\end{array}$ \\
\hline $\begin{array}{l}\text { g) Protein } \\
\text { subunits }\end{array}$ & $\begin{array}{l}\text { Potential protein particle is } \\
\text { injected which have the } \\
\text { ability to defeat the disease } \\
\text { causing virus. }\end{array}$ & $\begin{array}{l}\text { It is relatively safe. } \\
\text { Viral or bacterial } \\
\text { protein is used. It } \\
\text { can trigger the } \\
\text { immune response. }\end{array}$ & $\begin{array}{l}\text { Needed of } \\
\text { booster dose. } \\
\text { May be weaker } \\
\text { over time }\end{array}$ & BCG vaccine & $\begin{array}{l}18 \text { vaccines } \\
\text { are on the } \\
\text { race of } \\
\text { clinical trial }\end{array}$ & 40 \\
\hline h) VLP & $\begin{array}{l}\text { It is one kind of protein } \\
\text { vaccine that use viral } \\
\text { protein. }\end{array}$ & $\begin{array}{l}\text { The vaccine has self } \\
\text { adjuvental } \\
\text { properties and it is } \\
\text { comparatively safe } \\
\text { than other vaccines } \\
\text { as it does not } \\
\text { induce infection. }\end{array}$ & $\begin{array}{l}\text { There is } \\
\text { several } \\
\text { challenges to } \\
\text { produce the } \\
\text { vaccine by } \\
\text { maintaining } \\
\text { quality. }\end{array}$ & $\begin{array}{l}\text { Vaccine } \\
\text { candidate for } \\
\text { Chikungunya, } \\
\text { Japanese } \\
\text { Encephalitis, } \\
\text { Yellow Fever } \\
\text { and Zika Virus. }\end{array}$ & $\begin{array}{l}2 \text { vaccines } \\
\text { are on the } \\
\text { race of } \\
\text { clinical trial }\end{array}$ & $\begin{array}{l}41 \\
42\end{array}$ \\
\hline
\end{tabular}




\section{Different stages of Clinical trial of leading COVID-19 Vaccines}

In vaccine development pipeline, basic 3 phases are strictly maintained in clinical trials to assess the quality of a vaccine candidate. In phase 1 , a small number of healthy volunteers are tested, who have not been exposed to the pathogen to test the safety of the vaccine ${ }^{45}$. According to the latest data, Figure 2 indicates different phases of Covid-19 vaccine stages. For COVID-19 vaccine development process, 39\% of vaccines are in this stage. In phase 2 , after meeting the criteria for the first round, a vaccine candidate goes through the second round of testing. At this stage, it is recommended to keep focus on immunity and expansion of the vaccine across a wide population, allowing resilience to analyze considering age, gender, ethnicity, and other variables ${ }^{46}$. Presently, 11\% of COVID-19 vaccines are in the phase 2 . The success rate of this stage is often determined by whether the vaccine could decrease the number of cases or severity of the disease $^{25}$. At present, 30\% of COVID vaccines are on this phase. Till date, 15 different COVID-19 vaccines are being conducted phase 3 clinical trial hosted by several countries of different corners of the world (Table 2).

As on November 19, 2020, 117 vaccines are on trial in several stages. Figure 2 denoting the steps of Covid-19 vaccine. A total of 21 vaccines have completed stage 3 , and we are hoping to get effective candidate from those.

Table 2: Overall vaccine race up to date

\begin{tabular}{|c|c|c|c|c|c|c|}
\hline $\begin{array}{l}\text { Vaccine Candidate } \\
\text { Names }\end{array}$ & $\begin{array}{l}\text { Actual } \\
\text { Starting } \\
\text { Date of } \\
\text { Study }\end{array}$ & $\begin{array}{l}\text { Estimated } \\
\text { Completion } \\
\text { Date of Study }\end{array}$ & $\begin{array}{l}\text { Sponsor/Company } \\
\text { name }\end{array}$ & Vaccine type & $\begin{array}{l}\text { Developer } \\
\text { Country }\end{array}$ & $\begin{array}{l}\text { Succes } \\
\text { s rate }\end{array}$ \\
\hline $\begin{array}{l}\text { BNT162b3 } \\
\text { (NCT04368728) }\end{array}$ & $\begin{array}{l}\text { September 9, } \\
2020\end{array}$ & $\begin{array}{l}\text { December } \\
2021\end{array}$ & Pfizer and BioNTech & $\begin{array}{l}\text { Nucleoside } \\
\text { modified mRNA } \\
\text { (modRNA) }\end{array}$ & USA & $90 \%$ \\
\hline $\begin{array}{l}\text { ChAdOx1 nCoV-19 } \\
\text { (NCT04400838) } \\
\text { ISRCTN89951424 }\end{array}$ & $\begin{array}{l}\text { May 28, } \\
2020\end{array}$ & $\begin{array}{l}\text { September } \\
2021\end{array}$ & University of Oxford & $\begin{array}{l}\text { Viral vector- } \\
\text { based vaccines }\end{array}$ & UK & $70 \%$ \\
\hline $\begin{array}{l}\text { mRNA-1273 } \\
\text { (NCT04405076) }\end{array}$ & $\begin{array}{l}\text { May 29, } \\
2020\end{array}$ & $\begin{array}{l}\text { August } \\
20,2021\end{array}$ & ModernaTX, Inc. & $\begin{array}{l}\text { mRNA-based } \\
\text { vaccine }\end{array}$ & USA & $94.5 \%$ \\
\hline $\begin{array}{l}\text { Sputnik V vaccine } \\
\text { (NCT04526990) }\end{array}$ & & & $\begin{array}{l}\text { Gamaleya National } \\
\text { Research Centre for } \\
\text { Epidemiology and } \\
\text { Microbiology of the } \\
\text { Russian Healthcare } \\
\text { Ministry. }\end{array}$ & $\begin{array}{l}\text { Non-replicating } \\
\text { viral vector }\end{array}$ & Russia & $92 \%$ \\
\hline $\begin{array}{l}\text { Ad5-nCoV } \\
\text { (NCT04283461) }\end{array}$ & July 31, 2021 & $\begin{array}{l}\text { September 11, } \\
2020\end{array}$ & NPO Petrovax & $\begin{array}{l}\text { Recombinant } \\
\text { novel } \\
\text { coronavirus } \\
\text { vaccine }\end{array}$ & Canada & $40-70 \%$ \\
\hline $\begin{array}{l}\text { AZD1222 } \\
\text { (NCT04516746) }\end{array}$ & $\begin{array}{l}\text { August 28, } \\
2020\end{array}$ & $\begin{array}{l}\text { October 25, } \\
2022\end{array}$ & $\begin{array}{l}\text { The University of } \\
\text { Oxford; } \\
\text { AstraZeneca } \\
\text { IQVIA Serum } \\
\text { Institute of India }\end{array}$ & $\begin{array}{l}\text { Replication- } \\
\text { deficient viral } \\
\text { vector vaccine } \\
\text { (adenovirus } \\
\text { from } \\
\text { chimpanzees) }\end{array}$ & UK & $62-90 \%$ \\
\hline $\begin{array}{l}\text { CoronaVac } \\
\text { (NCT04456595) }\end{array}$ & July 21,2020 & October 2021 & Sinovac & $\begin{array}{l}\text { Inactivated } \\
\text { vaccine (formalin } \\
\text { with alum } \\
\text { adjuvant) }\end{array}$ & China & $90 \%$ \\
\hline $\begin{array}{l}\text { JNJ-78436735 (formerly } \\
\text { Ad26.COV2.S) } \\
\text { (NCT04614948) }\end{array}$ & $\begin{array}{l}\text { November 6, } \\
2020\end{array}$ & May 11, 2023 & Johnson \& Johnson & $\begin{array}{l}\text { Non-replicating } \\
\text { viral vector }\end{array}$ & USA & - \\
\hline $\begin{array}{l}\text { NVX- } \\
\text { CoV2373(NCT04611802) }\end{array}$ & $\begin{array}{l}\text { November } \\
2020\end{array}$ & $\begin{array}{l}\text { December } 30 \text {, } \\
2022\end{array}$ & Novavax & $\begin{array}{l}\text { Nanoparticle } \\
\text { vaccine }\end{array}$ & USA & - \\
\hline
\end{tabular}

https://covid-nma.com/vaccines/mapping/

(https://www.raps.org/news-and-articles/news-articles/2020/3/covid-19-vaccine-tracker)

(https://tbsnews.net/world/who-are-frontrunners-race-covid-vaccine-146320)

https://www.bbc.com/news/health-51665497

(https://clinicaltrials.gov/ct2/search)

https://www.biopharmadive.com/news/coronavirus-vaccine-pipeline-types/579122/

Fobs statistics.

https://www.forbes.com/sites/niallmccarthy/2020/11/23/how-effective-are-the-covid-19-vaccine-candidatesinfographic/?sh=5b15f914205d 


\section{Covid-19 Vaccine Stages}

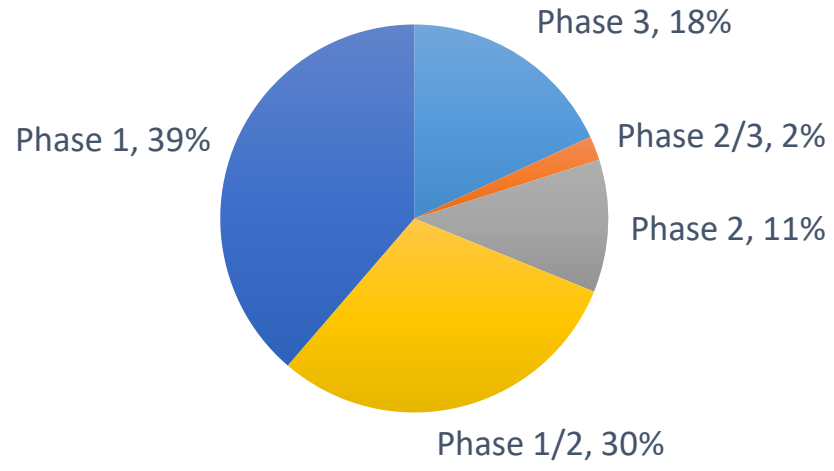

Phase $3 \square$ Phase $2 / 3 \square$ Phase $2 \square$ Phase $1 / 2 \square$ Phase 1

Figure 2: Different phases of COVID-19 vaccine and its required time duration.

\section{Top leading countries towards the vaccine race}

In COVID-19 vaccine race, several countries including but not limited to the United Kingdom, the United States, the people's republic of China, Russia, and India are most probably on the front line. Among them, Oxford/ AstraZeneca: AZD1222 from England, BioNTech/Pfizer: BNT162b2 and Moderna: mRNA-1273 from USA, Sinovac: CoronaVac from China, Sputnik V from Russia and, Bharat BioTech's Covaxin from India have shown promising outcomes in phase 3 clinical trial. So, the people from over the world are optimistic to get a successful vaccine candidate from the above mentioned vaccines.
BioNTech is a German company made partnership with Pfizer to develop a vaccine which is very much effective against COVID known as BNT162b2, the generic name of this vaccine tozinameran or the brand name Comirnaty

In vaccine race, BNT162b3 (NCT04368728), ChAdOx1 nCoV19, mRNA- 1273, Sputnik V vaccine, Ad5-nCoV shows promising result in phase 3 clinical trial. Till date, top leading vaccine candidates namely, BioNTech/Pfizer: BNT162b2, Moderna: mRNA-1273, Gamaleya: Sputnik V, Sinopharm: BBIBP-CorV have gotten acceptance on several countries (Table 3).

Table 3: Approved Vaccines

\begin{tabular}{|c|c|c|}
\hline Name of the vaccine & Developer & Approved Countries \\
\hline $\begin{array}{l}\text { BioNTech/Pfizer: } \\
\text { BNT162b2 }\end{array}$ & BioNTech, Pfizer & $\begin{array}{l}\text { Bahrain, Canada, Saudi Arabia ,United Kingdom, } \\
\text { United States, Chile ,Costa Rica, Ecuador, Kuwait, } \\
\text { Mexico, Panama, Singapore, Switzerland Israel. }\end{array}$ \\
\hline Moderna: mRNA-1273 & Moderna, NIAID & United States and Canada \\
\hline Gamaleya: Sputnik V & $\begin{array}{l}\text { Gamaleya Research Institute, Health Ministry of } \\
\text { the Russian Federation }\end{array}$ & Russia and Belarus \\
\hline Sinopharm: BBIBP-CorV & $\begin{array}{l}\text { China National Biotec Group Company Limited, } \\
\text { G42 Healthcare company, Abu Dhabi Health } \\
\text { Services Company, Wuhan Institute of Biological } \\
\text { Products Co. Ltd, Beijing Institute of Biological } \\
\text { Products Co. Ltd }\end{array}$ & United Arab Emirates, China, Bahrain \\
\hline
\end{tabular}

Source: https://covid19.trackvaccines.org/vaccines/

\section{BNT162b3 (NCT04368728) a Promising Hope}

So far BNT 162B3 is the most likely vaccine candidate. At first Canada and USA allowed it for only temporal use. However, detailed data and regulatory review is required for its final approval ${ }^{47}$.

The BNT 1622B3 vaccine is now the world's most promising vaccine, sponsored by BioNtech RNA Pharmaceuticals $\mathrm{GmbH}$, based on preliminary data that has been shown to be more than $90 \%$ effective in preventing Covid-19 (https://www.npr.org/sections/health-

shots/2020/11/24/938591815/pfizers-coronavirusvaccine-supply-contract-excludes-many-taxpayerprotections). The 43,538 participants were considered in Phase 3, which will go through a definitive final analysis in 164 cases. Germany, Argentina, Brazil, South Africa, Turkey, United States of America, and Japan were chosen for its 
phase 3 trail. About 76 million doses reserved by Canada for the BioNtech potential vaccine candidate.

A clinical trial was completed by this company and confirmed that the vaccine has a power of preventing 95 percent Covid-19 pathogens (https://www.nytimes.com/.). An Emergency Use Authorization (EUA) for the PfizerBioNTech COVID-19 (BNT162b2) vaccine (Pfizer, Inc; Philadelphia, Pennsylvania) was released on December 11, 2020 by the Food and Drug Administration (FDA), a lipid nanoparticle-formulated, nucleoside-modified mRNA vaccine encoding the SARS-CoV-2 perfusion spike glycoprotein, the virus that causes coronavirus disease 2019 (COVID-19). The Pfizer-BioNTech vaccine COVID-19 consists of 2 doses, each intramuscularly administered (30 $\mu \mathrm{g}, 0.3$ mL, 3 weeks apart). On December 12, 2020, the Advisory Committee on Immunization Practices (ACIP) issued an interim recommendation for use of the Pfizer-BioNTech COVID-19 vaccine in persons aged $\geq 16$.

\section{Drawbacks of the vaccines of Covid-19 vaccines}

Most of the vaccines against COVID-19 have shortcomings. Most of them are based on a common cold virus that many people have been exposed to, potentially limiting their effectiveness. As well as most of them are made using adenovirus vector this has many drawbacks even it could enhance the chance of HIV48. Another main obstacle which we have to face is preservation problem of the vaccine at much less temperature like $-80^{\circ} \mathrm{C}^{49}$ and it is assuming that the patients having allergic problem could not take this vaccine.

\section{Concluding remarks and future prospects}

Although novel coronavirus disease 2019 (COVID-19) was first reported in late 2019 at Wuhan, a city of central China, it travelled rest of the world in 2020 as a deadly one that created a pandemic situation. Therefore, it can be said that 2020 was the year of COVID-19. Till date, it is reported that 81.7 million people got infected worldwide and 1.78 million died. To avoid further loss of life, a successful vaccine candidate is an emergency issue. An effective COVID-19 vaccine is the need of the hour which can awaken a suitable immunity to stop this epidemic. There are currently a number of potential vaccine candidates that shows promising result in clinical trials. Recently, top leading vaccine candidates namely, BioNTech/Pfizer; BNT162b2, Moderna; mRNA-1273, Gamaleya; Sputnik V, Sinopharm; BBIBP-CorV got approval in different parts of the world that are expected to hit the market as early as 2021 for saving every single loss of life.

\section{Declarations}

\section{Funding}

The authors received no specific funding for this study

\section{Competing Interest}

Authors have no conflicts of interest.

\section{Ethics Approval}

Not required

\section{Consent to participate}

Not applicable

\section{Consent for Publication}

Not applicable

\section{Availability of Data and Material}

All the relevant data are within the manuscript

\section{Authors Contributions}

MRC, SI, MNM developed the concept, involved in literature study and wrote the draft manuscript. MNM revised the manuscript and assisted with literature search. MNM supervised the work and approved the manuscript for submission. All the authors carefully read the manuscript.

\section{Acknowledgments}

The authors wish to thank Dr. Md Mahmudul Islam Joy, Guangzhou Institutes of Biomedicine and Health, Chinese Academy of Sciences, University of Chinese Academy of Science, for critical review of the article.

\section{References}

1. Rabi FA, Al Zoubi MS, Al-Nasser AD, Kasasbeh GA, Salameh DM. Sars-cov-2 and coronavirus disease 2019: What we know so far. Pathogens 2020; 9(3). https://doi.org/10.3390/pathogens9030231

2. Hu B, Ge X, Wang LF, Shi Z. Bat origin of human coronaviruses Coronaviruses: Emerging and re-emerging pathogens in humans and animals Susanna Lau Positive-strand RNA viruses. Virol J 2015; 12(1). https://doi.org/10.1186/s12985-015-0422-1

3. Fani M, Teimoori A, Ghafari S. Comparison of the COVID-2019 (SARS-CoV-2) pathogenesis with SARS-CoV and MERS-CoV infections. Future Virol 2020; 15(5): 317-323. https://doi.org/10.2217/fvl-2020-0050

4. Park SE. Epidemiology, virology, and clinical features of severe acute respiratory syndrome-coronavirus-2 (SARS-CoV-2; Coronavirus Disease-19). Clin Exp Pediatr. 2020; 63(4):119124. https://doi.org/10.14776/piv.2020.27.e9

5. Pyrek K. 100 Years after the Spanish Flu: Lessons Learned and Challenges for the Future. Infection Control Today. 2018; 11. https://www.infectioncontroltoday.com/view/100-years-afterspanish-flu-lessons-learned-and-challenges-future

6. Kaur SP, Gupta V. COVID-19 Vaccine: A comprehensive status report. Virus research. 2020; 288:198114. https://doi.org/10.1016/j.virusres.2020.198114

7. Eastin C, Eastin T. Risk Factors Associated With Acute Respiratory Distress Syndrome and Death in Patients With Coronavirus Disease 2019 Pneumonia in Wuhan, China. J Emerg Med 2020; 58: 713-

714.https://doi.org/10.1016/j.jemermed.2020.04.007

8. Gaye B, Fanidi A, Jouven X. Denominator matters in estimating COVID-19 mortality rates. Eur Heart J 2020;41: 3500.https://doi.org/10.1093/eurheartj/ehaa282

9. Li G, He X, Zhang L, Ran Q, Wang J, Xiong A, Wu D, Chen F, Sun J, Chang C. Assessing ACE2 expression patterns in lung tissues in the pathogenesis of COVID-19. J Autoimmun. 2020; 112:102463. https://doi.org/10.1016/j.jaut.2020.102463

10. Mulligan MJ, Lyke KE, Kitchin N, Absalon J, Gurtman A, Lockhart S, Neuzil K, Raabe V, Bailey R, Swanson KA, Li P. Phase I/II study of COVID-19 RNA vaccine BNT162b1 in adults. Nature 2020; 586:589-593. https://doi.org/10.1038/s41586-020-2639-4

11. Wu SC. Progress and Concept for COVID-19 Vaccine Development. Biotechno j2020; 15: e2000147.

12. Wu A, Peng Y, Huang B, Ding X, Wang X, Niu P, Meng J, Zhu Z, Zhang Z, Wang J, Sheng J. Genome composition and divergence of the novel coronavirus (2019-nCoV) originating in China. Cell host microbe 2020; 27(3): 325-328. https://doi.org/10.1016/j.chom.2020.02.001

13. Rogstam A, Nyblom M, Christensen S, Sele C, Talibov VO, Lindvall T, Rasmussen AA, André I, Fisher Z, Knecht W, Kozielski F. Crystal Structure of Non-Structural Protein 10 from Severe Acute Respiratory Syndrome Coronavirus-2. Int J Mol Sci 2020; 21:7375. https://doi.org/10.3390/ijms21197375

14. Dutta NK, Mazumdar K, Gordy JT. The nucleocapsid protein of SARS-CoV-2: a target for vaccine development. J Virol 2020; 94. https://doi.org/10.1128/jvi.00647-20

15. Joshi T, Sharma P, Joshi T, Pundir H, Mathpal S, Chandra S. Structure-based screening of novel lichen compounds against SARS Coronavirus main protease (Mpro) as potentials inhibitors of COVID-19. Mol Divers 2020; 29:1-3. 
https://doi.org/10.1007/s11030-020-10118-x

16. Zhu W, Chen CZ, Gorshkov K, Xu M, Lo DC, Zheng W. RNAdependent RNA polymerase as a target for COVID-19 drug discovery. SLAS DISCOV 2020; 25:1141-51. https://doi.org/10.1177/2472555220942123

17. Renardy M, Eisenberg M, Kirschner D. Predicting the second wave of COVID-19 in Washtenaw County, MI. J Theor Biol2020; 507:110461. https://doi.org/10.1016/j.jtbi.2020.110461

18. Nazareth J, Minhas JS, Jenkins DR, Sahota A, Khunti K, Haldar P, Pareek M. Early lessons from a second COVID-19 lockdown in Leicester, UK. J Clean Prod 2020; 18:396(10245):e4-5 .https://doi.org/10.1016/S0140-6736(20)31490-2

19. Wujtewicz M, Dylczyk-Sommer A, Aszkiełowicz A, Zdanowski S, Piwowarczyk S, Owczuk R. COVID-19-what should anaethesiologists and intensivists know about it? Anaesthesiol Intensive Ther 2020; 52:34-41.

20. Corey L, Mascola JR, Fauci AS, Collins FS. A strategic approach to COVID-19 vaccine R\&D. Science, 2020; 368(6494):948-950. https://doi.org/10.1126/science.abc5312

21. Gaebler C, Nussenzweig M C. All eyes on a hurdle race for a SARS-CoV-2 vaccine. Nature, 2020; 586(7830):501-502. https://doi.org/10.1038/d41586-020-02926-w

22. Speiser DE, Bachmann MF. Covid-19: Mechanisms of vaccination and immunity. Vaccines, 2020; 8:404 https://doi.org/10.3390/vaccines8030404

23. GAVI. The COVID-19 vaccine race. 2020. https://www.gavi.org/vaccineswork/covid-19-vaccine-race

24. Nile SH, Kai G. Recent Clinical Trials on Natural Products and Traditional Chinese Medicine Combating the COVID-19. Indian J Microbiol 2020; 30:1-6. 10.1007/s12088-020-00919-x.

25. Singh K, Mehta S. The clinical development process for a novel preventive vaccine: An overview. J Postgrad Med 2016;62: 4-11. https://doi.org/10.4103/0022-3859.173187

26. Gralinski LE, Menachery VD. Return of the coronavirus: 2019nCoV. Viruses, 2020; 12:135. https://doi.org/10.3390/v12020135

27. Beniac DR, Andonov A, Grudeski E, Booth TF. Architecture of the SARS coronavirus prefusion spike. Nat Struct Mol Biol, 2006; 13(8):751-752. https://doi.org/10.1038/nsmb1123

28. Chaudhry SN, Hazafa A, Mumtaz M, Kalsoom U, Abbas S, Kainaat A, Bilal S, Zafar N, Siddique A, Zafar A. New insights on possible vaccine development against SARS-CoV-2. Life Sciences, 2020; 260:118421 https://doi.org/10.1016/j.lfs.2020.118421

29. Wang J, Peng Y, Xu H, Cui Z, Williams RO. The COVID-19 Vaccine Race: Challenges and Opportunities in Vaccine Formulation. AAPS PharmSciTech, 2020; 21:1-2. https://doi.org/10.1208/s12249-020-01744-7

30. Du L, Zhao G, Lin Y, Sui H, Chan C, Ma S, He Y, Jiang S, Wu C, Yuen KY, Jin DY. Intranasal Vaccination of Recombinant AdenoAssociated Virus Encoding Receptor-Binding Domain of Severe Acute Respiratory Syndrome Coronavirus (SARS-CoV) Spike Protein Induces Strong Mucosal Immune Responses and Provides Long-Term Protection against SARS-CoV Infection. The Journal of Immunology, 2008; 180:948-956. https://doi.org/10.4049/jimmunol.180.2.948

31. Novavax. Novavax to Present COVID-19 Vaccine Candidate Progress in World Vaccine Congress Webinar Series. 2020.

32. Jeyanathan M, Afkhami S, Smaill F, Miller MS, Lichty BD, Xing Z. Immunological considerations for COVID-19 vaccine strategies. Nat Rev Immunol 2020; 20:615-32 https://doi.org/10.1038/s41577-020-00434-6

33. Aicha Sow A. COVID-19 vaccine update: Pfizer may be the frontrunner, but Canada has hedged its bets. The Conversation. 2020.

34. Callaway $\mathrm{E}$. The race for coronavirus vaccines: a graphical guide. Nature, 2020; 580:576-577. https://doi.org/10.1038/d41586020-01221-y

35. Amanna IJ, Slifka MKSuccessful vaccines. Curr Top Microbiol Immunol2020; 428:1-30. https://doi.org/10.1007/82_2018_102

36. mRNA vaccines- a new era in vaccinology | Nature Reviews Drug Discovery. (n.d.). Retrieved from https://www.nature.com/articles/nrd.2017.243

37. Blackburn L. RNA vaccines: an introduction. 2018 PHG Foundation, University of Cambridge, Cambridge, UK

38. Kong W, Ye J, Guan S, Liu J, Pu J. Epidemic Status of Swine Influenza Virus in China," Indian J Microbiol 2014; 54:3- 11, doi: 10.1007/s12088-013-0419-7

39. Smith TR, Patel A, Ramos S, Elwood D, Zhu X, Yan J, Gary EN, Walker SN, Schultheis K, Purwar M, Xu Z. Immunogenicity of a DNA vaccine candidate for COVID-19. Nature Communications 2020; 11: 1-3. https://doi.org/10.1038/s41467-020-16505-0

40. What are viral vector-based vaccines and how could they be used against COVID-19? (n.d.).

41. van Riel D, de Wit E. Next-generation vaccine platforms for COVID-19. Nature Materials, 2020; 19(8): 810-812. https://doi.org/10.1038/s41563-020-0746-0

42. Yang J, Wang W, Chen Z, Lu S, Yang F, Bi Z, Bao L, Mo F, Li X, Huang $Y$, Hong W. A vaccine targeting the RBD of the $S$ protein of SARS-CoV-2 induces protective immunity. Nature, 2020; 586(7830): 572-577. https://doi.org/10.1038/s41586-0202599-8

43. Fuenmayor J, Gòdia F, Cervera L.Production of virus-like particles for vaccines. New Biotechnology, 2017; 39: 174-180. https://doi.org/10.1016/j.nbt.2017.07.010

44. Garg H, Mehmetoglu-Gurbuz T, Joshi A. Virus Like Particles (VLP) as multivalent vaccine candidate against Chikungunya, Japanese Encephalitis, Yellow Fever and Zika Virus. Scientific Reports, 2020; 10:1-3. https://doi.org/10.1038/s41598-02061103-1

45. Grode L, Ganoza CA, Brohm C, Weiner 3rd J, Eisele B, Kaufmann SH. Safety and immunogenicity of the recombinant BCG vaccine VPM1002 in a phase 1 open-label randomized clinical trial. Vaccine2013; 31:1340-1348. https://doi.org/10.1016/j.vaccine.2012.12.053

46. Roestenberg M, Kamerling I, de Visser SJ. Controlled human infections as a tool to reduce uncertainty in clinical vaccine development. Frontiers in Medicine, 2018; 5:297. https://doi.org/10.3389/fmed.2018.00297

47. Canada Authorizes Use Of Pfizer COVID-19 Vaccine. (n.d.). https://www.npr.org/sections/coronavirus-liveupdates/2020/12/09/944621350/canada-authorizes-use-ofpfizer-covid-19-vaccine

48. Anon-31. Scientists see downsides to top Covid-19 vaccines from Russia, China. 2020; ETHealthworld.

49. Fikiin K. The biggest challenge for COVID-19 vaccines is the cold supply chain. 2020;

https://www.euractiv.com/section/coronavirus/opinion/thebiggest-challenge-for-covid-19-vaccines-is-the-cold-supplychain/ 